\title{
TANGGUNG JAWAB HUKUM PRESIDEN DALAM PEMBERIAN IZIN PEMERIKSAAN PEJABAT NEGARA
}

\author{
M. Sabaruddin Sinapoy \\ Fakultas Hukum Universitas Haluhaleo \\ email : sabaruddinsinapoy@yahoo.com
}

\begin{abstract}
Basically the law enforcement authority granted to juridical constitutional judiciary and its parts. The parts in question here include, police, prosecutors, and the Judiciary, and in addition there are also other parts like, Lawyer (Advocate), Community Organization in the field of law, such as the Legal Aid Institute (LBH), and others. Therefore, in addition to the judiciary and its parts are one of the agencies that have functions in the field of law enforcement, but the agency today has a function in the field of law enforcement. This empirical fact is an institution that meant the President, which is constitutionally known that the President is a state agency that has the "authority in the field of government" expressed in Article 4 paragraph (1) of the 1945 Constitution.
\end{abstract}

Keyword: Power, President, State Agency

\begin{abstract}
Abstrak
Pada dasarnya kewenangan penegakkan hukum secara yuridis konstitusional diberikan pada lembaga peradilan dan bagian-bagiannya. Bagian-bagian yang dimaksud disini meliputi, Kepolisian, Kejaksaan, dan Kehakiman, dan selain itu ada pula bagian-bagian lain seperti, Pengacara (Advokad), Organisasi Masyarakat yang bergerak dibidang hukum, seperti Lembaga Bantuan Hukum (LBH), dan lain sebagainya. Oleh sebab itu selain lembaga peradilan dan bagian-bagiannya terdapat salah satu lembaga yang mempunyai fungsi dibidang pelaksanaan hukum, tetapi lembaga tersebut saat ini juga mempunyai fungsi dalam bidang penegakkan hukum. Fakta empiris ini yang dimaksudkan adalah lembaga Presiden, dimana diketahui secara konstitusional bahwa Presiden merupakan lembaga Negara yang memiliki "kekuasaan dibidang pemerintahan" tersurat dalam Pasal 4 ayat (1) UUD 1945.
\end{abstract}

Kata Kunci: Kekuasaan, Presiden, Lembaga Negara.

\section{Pendahuluan}

Negara Republik Indonesia adalah negara yang berdasarkan atas hukum (Rechtstaat) dan bukan negara yang berdasarkan kekuasaan belaka (machstaat), demikian penjelasan Undang-Undang Dasar 1945. Indonesia sebagai negara berdasarkan hukum menjunjung hak asasi manusia dan menjamin semua warga negara bersamaan kedudukannya di dalam hukum dan pemerintahan tanpa ada kecualinya. 
Beberapa ketentuan hasil amandemen UUD 1945 telah membawa pengaruh terhadap sistem ketatanegaraan Indonesia, khususnya pada penguatan kualitas kedaulatan rakyat dan demokrasi dengan memberi ruang besar bagi partisipasi rakyat dalam ikut menentukan pengisianpengisian jabatan publik secara langsung seperti pemilihan Presiden dan Wakil Presiden secara langsung, melalui sistem proporsional terbuka. Menurut Harun Al Rasid, sistem tersebut dengan sendirinya meningkatkan partisipasi rakyat dalam menentukan kebijakan berkenaan dengan kepentingannya yang mengharuskan pejabat publik senan tiasa berhati-hati dalam menentukan kebijakan (beleid). Atas dasar itu, setiap tindakan pejabat menjadi titik awal dari pertanggungjawabannya terhadap rakyat yang memilihnya, baik secara organisasi maupun karena jabatannya. ${ }^{1}$

Dalam pelaksanaan penyelenggaraan pemerintahan di Indonesia yang dilandasi UUD 1945 dimana fungsi dan wewenang lembaga penyelenggara pemerintahan ada yang diberikan langsung oleh UUD 1945 dan diberikan oleh UU sebagai pelaksanaan UUD 1945. Konsep tersebut mengenai keberadaan lembaga penyelenggara pemerintahan (lembaga Negara) mengingatkan kita pada seorang filsuf hukum terkemuka (Montesquieu) yang memperkenalkan sebuah konsep trias politika, dimana konsep tersebut membagi kekuasaan lembaga penyelenggara negara dalam tiga bagian, yaitu eksekutif, legislatif,

\footnotetext{
${ }^{1}$ Harun Al Rasid, Pengisian Jabatan Presiden, Grafiti, Jakarta, 1999, hlm. 33-34.
}

dan yudisial. Kekuasaan lembaga legislatif, adalah kekuasaan dibidang pembentukan perundang-undangan (legislasi), sedangkan kekuasaan lembaga eksekutif adalah melaksanakan ketentuan perundangundangan yang telah dibentuk dan ditetapkan oleh legislatif, dan kekuasaan lembaga yudikatif adalah menjaga kridibilatas dan eksistensi perundang-undangan yang dibentuk oleh legislatif serta memberikan penafsiran hukum terhadap ketentuan perundang-undangan yang berlaku.

Konsepsi trias politika yang diidealkan oleh Montesquieu jelas tidak relevan lagi dewasa ini, mengingat tidak mungkin lagi mempertahankan bahwa ketiga organisasi tersebut hanya berurusan secara ekslusif dengan salah satu dari ketiga fungsi kekuasaan tersebut. Kenyataan dewasa ini menunjukkan bahwa hubungan antara cabang kekuasaan itu tidak mungkin tidak saling bersentuhan, dan bahkan ketiganya bersifat sederajat dan saling mengendalikan satu sama lain sesuai dengan prinsip checks and balances. ${ }^{2}$

Apa yang diungkapkan oleh Jimly tersebut merupakan sebuah konsep pemikiran yang maju dalam dinamika ilmu ketatanegaraan, sehingga pandangan tersebut dapat dijadikan perhatian khusus dalam menyusun UUD 1945 selanjutnya. Hal ini dikatakan bahwa kenyataan dinamika penyelenggaraan kekuasaan pemerintahan saat ini tidak lagi dikatakan tunduk pada konsep trias politika, sebagaimana fakta dalam pembatasan analisi ini yang didasari

2 Jimly Asshiddiqie, Perkembangan \& Konsolidasi Lembaga Negara Pasca Reformasi, Sinar Grafika, Edisi Kedua, Cetakan pertama, Jakarta, 2010, hlm. 31. 
pada adanya kewenangan Presiden dalam kaitannya dengan penegakkan hukum.

Menurut Belifante, bahwa Pemerintahan dapat disamakan dengan kekuasaan eksekutif ${ }^{3}$. Menurut Diana Halim Koentjoro yang dimaksud dengan urusan pemerintahan adalah semua kegiatan yang bersifat eksekutif yang tidak merupakan kegiatan pembuatan peraturan perundangundangan (legislatif) dan juga bukan kegiatan mengadili (yudikatif). Dapat dikatakan bahwa urusan pemerintahan adalah kegiatan public services. ${ }^{4}$

Apa yang diketengahkan oleh ahli tersebut maka kekuasaan Presiden yang dimaksud Pasal 4 ayat (1) UUD 1945 kekuasaan dibidang administrasi negara yang melaksanakan fungsi untuk menyelenggarakan urusan pemerintahan baik di pusat maupun di daerah. Sedangkan yang dimaksud "urusan pemerintahan" ialah kegiatan yang bersifat eksekutif5.

Kembali pada fakta penegakkan hukum saat ini yang diliputi pula adanya domain lembaga pemerintahan (Presiden), yaitu dalam tataran praktiknya adalah bahwa dalam hal pejabat pemerintahan negara baik dipemerintahan pusat maupun pemerintahan daerah, yang diduga melakukan perbuatan melawan hukum seperti korupsi, maka sudah menjadi kewenangan pihak penyidik (polisi maupun jaksa) untuk melaksanakan pemanggilan kepada pejabat tersebut guna

\footnotetext{
${ }^{3}$ A.D. Belifante, dalam Diana Halim Koentjoro, Hukum Administrasi Negara, Ghalia Indonesia, Cetakan Pertama, Bogor, 2004, hlm. 9.

4 Ibid., hlm. 28.

5 Penjelasan Pasal 1 angka 1 UU Peradilan Tata Usaha Negara
}

dilakukan pemeriksaan atas dugaan tersebut. Kewenangan penyidik baik kepolisian maupun kejaksaan merupakan kewenangan yang diberikan secara konstitusional, yakni tidak diragukan lagi dalam melakukan pemanggilan dan pemeriksaan secara yuridis formal. Namun yang menjadi fenomena saat ini adalah ketika pemanggilan pejabat Negara tersebut dilaksanakan oleh penyidik, maupun penuntut guna dilakukan pemeriksaan, terlebih dahulu harus ada sebuah surat isin pemeriksaan yang dikeluarkan/diberikan dari Presiden.

Adanya surat isin pemeriksaan dari Presiden tersebut, merupakan dinamika baru dalam penegakkan hukum, sehingga untuk itu pelaksanaan penegakkan hukum terkadang dirasakan tidak demokrasi konstitusional lagi. Dengan demikian maka uraian tersebut merupakan titik akhir dalam membatasi analisi hukum yang dijadikan sebagai isu sentral pada pembahasan berikutnya.

\section{Konsep Tanggung Jawab Hukum}

Luas lingkup serta dalamnya makna tanggung jawab dan posisinya sebagai objek multidisiplin menyebabkan pertanggungjawaban memiliki banyak pengertian dan beraneka ragam bentuk, sehingga untuk memahaminya secara konseptual dan kontekstual dibutuhkan bantuan berbagai ragam disiplin ilm seperti, hukum, politik, administrasi, sosial dan budaya. $^{6}$

Perlu ditegaskan kembali bahwa

\footnotetext{
${ }^{6}$ Soejono Soemargono, Pengantar Filsafat, Tiara
} Wacana, Cetakan Keenam, Yogyakarta, 1995, hlm. 54. 
eksistensi pertanggungjawaban merupakan konsekuensi yang lahir dan terbentuk dari tanggung jawab. Prediksi tanggung jawab, baik yang lahir sebagai akuntabilitas, obligasi maupun kausa, tergantung kepada konteks dan kapabilitas tanggung jawab. Kapabilitas tanggung jawab dipengaruhi oleh kedudukan, pengetahuan, pilihan dan maksud dari suatu tindakan yang harus dipertanggungjawabkan. Bentuk pertanggungjawaban tergantung kepada kualifikasi tanggung jawab. Dua means stream kualifikasi tanggung jawab antara lain; pertama, tanggung jawab moral; dan kedua, tanggung jawab politis. Kedua kerangka dasar tanggung jawab tersebut menjadi alas berpikir untu secara rasional menempatka pertanggungjawaban atas tindakan pemerintah sebagai organisasi dan pribadi jabatan. $^{7}$

Secara sederhana, pertanggungjawaban hukum dapat dipahami sebagai suatu bentuk pertanggungjawaban oleh karena hukum menentukan demikian bahwa subjek hukum bertanggung jawab (Subjek hukum adalah pengembang hak dan kewajiban. Subjek hukum terdiri dari manusia (natuurlijke person) dan badan hukum (rechtspersoon)). Akan tetapi, dalam kenyataannya tidak semua subjek hukum yang ditentukan oleh hukum untuk menanggung suatu pertanggungjawaban serta merta kepadanya dapat dimintai pertanggungjawaban, oleh karena beberapa unsur untuk menentukan suatu subjek hukum menanggung suatu

\footnotetext{
${ }^{7}$ Dennis F. Thompson, Political Ethics and Public Office, President and Fellows of Harvard College, 1993. Diterjemahkan oleh Yayasan Obor Indonesia dengan judul, Etika Politik Pejabat Negara, Jakarta, 2002, hlm. 91.
}

pertanggungjawaban. ${ }^{8}$

Sementara responsibility berarti, "The state of being answerable for an obligation, and includes judgment, skill, ability and capacity" (hal dapat dipertanggungjawabkan atas suatu kewajiban, dan termasuk putusan, keterampilan, kemampuan, dan kecakapan). Responsibility juga berarti, "The obligation to answer for an act done, and to repair or otherwise make restitution for any injury it may have caused", (kewajiban bertanggung jawab atas undang-undang yang dilaksanakan, dan memperbaiki atausebaliknya-memberi gati rugi atas kerusakan apa pun yang telah ditimbulkannya). Dari responsibility ini muncul istilah responsible government; "This term generallydesignates that species of governmental system in which the responsibility for public measures or acts $f$ state rests upon the ministry or executive council, who are under an obligation to resign when disapprobation of their course is expressed by a vote of want of confidence, in the legislative assembly, or by the defeat of an important measure advocated by them", 9 yang menunjukkan bahwa, (istilah ini pada umumnya menunjukkan bahwa jenis-jenis pemerintahan dalam hal mana pertanggungjawaban terhadap ketentuan atau undang-undang publik dibebankan pada departemen atau dewan eksekutif, yang harus mengundurkan diri apabila penolakan terhadap kinerja mereka dinyatakan melalui

\footnotetext{
${ }^{8}$ Mochtar Kusumaatmadja et. al., Pengantar Ilmu Hukum: Suatu Pengenalan Pertama Ruang Lingkup Berlakunya Ilmu Hukum, Alumni, Buku I, Bandung, 2000, hlm. 80 .

9 Hendry Campbell Black, Black's Law Dictionary, Fifth Edition, (USA: ST. Paul Minn, West Publishing Co, 1979, hlm. 1180.
} 
mosi tidak percaya, di dalam majelis legislatif, atau melalui pembatalan terhadap suatu undang-undang penting yang dipatuhi mereka). ${ }^{10}$ Dalam istilah Belanda juga dikenal ada dua istilah, yaitu aansprakelijk dan verantwoordelik. ${ }^{11}$

Dalam kamus hukum, ansprakelijk berarti "Verboden, verantwoordelijk, in rechte gehouden voor enige schuld of voor de gevolgen van enig feit of enige handeling (terikat, bertanggung jawab, bertanggung jawab menurut hukum atas kesalahan atau akibat suatu perbuatan). Dari istilah ini muncul istilah pertanggungjawaban berdasarkan undang-undang; "Wettelijk ansprakelijkheid is gehoudenheid tot schadevergoeding uit onrechtmatige daad" (pertanggungjawaban menurut undangundang, yaitu kewajiban mengganti kerugian yang timbul karena perbuatan melanggar hokum). ${ }^{12}$

Berdasarkan prespektif hukum
dalam kehidupan sehari-hari dikenal
istilah rechtsverkeer, yang didalamnya mengsyaratkan adanya tindakan hukum (rechtshandeling) dan hubungan hukum (rechtsbetrekking) antar subjek hukum. Pergaulan, tindakan, dan hubungan hukum adalah kondisi atau keadaan yang diatur oleh hukum dan/atau memiliki relevansi hukum. Dalam hal ini terjadi interaksi hak dan kewajiban antar dua subjek hukum atau lebih, yang masing-masing dilekati hak dan kewajiban (rechten en plichten). Hukum

\footnotetext{
10 Ridwan HR, Hukum Administrasi Negara, Edisi Revisi, Rajawali Pers, Jakarta, 2011, hlm. 319.

11 Ibid., hlm. 320.

12 SJ. Fockema Andreae, Rechtsgeleerd Handwoordenboek, Tweede Druk, J.B. Wolter, Uitgeversmaatshappij N.V., Groningen, 1951, hlm. 4
}

diciptakan untuk mengatur pergaulan hukum agar masing-masing subjek hukum menjalankan kewajibannya secara benar dan memperolehhaknyasecarawajar.Disamping itu, hukum juga difungsikan sebagai instrument perlindungan (bescherming) bagi subjek hukum. Dengan kata lain, hukum dicitakan agar keadilan terimplementasi dalam pergaulan hukum. Ketika ada subjek hukum yang melalaikan kewajiban hukum yang seharusnya dijalankan atau melanggar hak subjek hukum lain, kepada yang melalaikan kewajiban dan melanggar hak itu dibebani tanggung jawab dan dituntut memulihkan atau mengembalikan hak yang sudah dilanggar tersebut. Beban tanggung jawab dan tuntutan ganti rugi atau hak itu ditujukan kepada setiap subjek hukum yang melanggar hukum, tidak perduli apakah subjek hukum itu seseorang, badan hukum, ataupun pemerintah. ${ }^{13}$

Dari uraian di atas terkait dengan pertanggungjawaban hukum, maka dapat disimpulkan pertanggungjawaban hukum terdiri dari tiga jenis, yaitu pertanggungjawaban hukum publik (hukum administrasi), pertanggungjawaban hukum perdata (privat), dan pertanggungjawaban hukum pidana. Ketiga jenis pertanggungjawaban hukum tersebut dapat diketahui dalam uraian sebagai berikut:

a. Pertanggungjawaban hukum publik (hukum administrasi) atau menurut Philipus M. Hadjon tanggung gugat TUN pada dasarnya adalah tanggung gugat jabatan. ${ }^{14}$

${ }^{13}$ Ibid., hlm. 321-322.

14 Philipus M. Hadjon, Hukum Administrasi dan Good Governance, Universitas Trisakti, Jakarta, 2010, hlm. 96. 
Telah disebutkan bahwa salah satu prinsip Negara hukum adalah asas legalitas, yang mengandung makna bahwa setiap tindakan hukum pemerintahan harus berdasarkan pada peraturan perundangundangan yang berlaku atau setiap tindakan hukum pemerintahan harus berdasarkan pada kewenangan yang diberikan oleh peraturan perundang-undangan. Dengan bersandar pada asas legalitas itulah pemerintah melakukan berbagai tindakan hukum. Karena pada setiap tindakan hukum itu mengandung makna penggunaan kewenangan, maka di dalamnya tersirat adanya kewajiban pertanggungjawaban, sesuai dengan prinsip "geen bevoegdheid zonder verantwoordelijkheid".

Tanggung jawab pemerintah terhadap warga Negara atau pihak ketiga dianut oleh hampir semua Negara yang berdasarkan atas hukum. Beberapa Negara yang secara tegas memberikan beban tanggung jawab kepada pemerintah, berdasarkan yurisprudensi maupun ketentuan hukum positifnya. ${ }^{15}$ Berdasarkan yurisprudensi Conseil d'Etat, pemerintah atau Negara dibebani membayar gati rugi kepada seseorang rakyat atau warga Negara yang menjadi korban pelaksanaan tugas administratif. Berdasarkan yurisprudensi yang ditentukan oleh House of Lords Inggris ditentukan bahwa raja atau pemerintah bertanggung jawab atas konsekuensi-konsekuensi yang tmbul akibat kelalaian dan kecerobohan pejabat pemerintah dalam menjamin keselamatan pelaksanaan tugas mereka.

15 Paulus E. Lotulung, Beberapa Sistem Tentang Kontrol Segi Hukum Terhadap Pemerintah, Citra Aditya Bakti, Bandung, 1993, hlm. 18.
Di Jerman, berdasarkan Pasal 839 Kitab Undang-Undang Hukum Sipil (BGB) ditentukan bahwa setiap badan hukum publik bertanggung jawab atas kesalahan yang dilakukan oleh setiap pegawai atau karyawannya bilamana pegawai yang bersangkutan telah "melalaikan kewajibannya sebagaimana yang telah dipercayakan kepadanya selaku petugas umum, sehingga menimbulkan kerugian terhadap pihak ketiga". Di Amerika baik pada tingkat federal maupun Negara bagian, pemerintah dapat dibebani tanggung jawab atas kesalahan yang dilakukan pada waktu pejabat pemerintah menjalankan tugasnya.

b. Tanggung jawab pidana adalah tanggung jawab pribadi, dalam kaitannyadengantindakpemerintahan, tanggung jawab pribadi seorang pejabat berhubungan dengan adanya maladministrasi. ${ }^{16}$

c. Tanggung jawab perdata dapat menjadi tanggung gugat jabatan berkaitan dengan perbuatan melanggar hukum oleh penguasa. Tanggung gugat perdata menjadi tanggung gugat pribadi apabila terdapat unsur maladministrasi. ${ }^{17}$

\section{Pertanggungjawaban Pemerintahan}

Pemerintah dalam karakter aktifnya dituntut untuk menyelenggarakan tugastugas pemerintahan (pelayanan public) yang semakin beragam dan rumit, sesuai dengan wewenang yang dimiliki. Hal tersebut merupakan suatu keharusan, oleh karena

\footnotetext{
${ }^{16}$ Philipus M. Hadjon, Op., cit, hlm. 96.

${ }^{17}$ Ibid.
} 
hokum administrasi adalah hokum yang berkaitan dengan wewenang pemerintahan dan control terhadap penggunaan wewenang yang tujuannya untuk melindungi individu atau masyarakat. ${ }^{18}$ Akan tetapi dalam penyelenggaraan pemerintahan ataupun pelayanan public penggunaan wewenang pemerintahan masih sering terjadi kesalahan-kesalahan dan penyimpanganpenyimpangan.

Sehingga, konsepsi onrechtmatige daad menjadi bagian paling sulit dalam ilmu hukum pada saat konsep ini diterapkan pada pemerintah apalagi ketika hukum tidak tertulis dimasukkansebagaisalahsatukriteria perbuatan melanggar hukum. Dibawah tema "the leerstuk der onrechtmatige overheidsdaad", kebanyakan para sarjana hukum berdebat menyangkut apakah pemerintah dapat diajukan ke pengadilan dan dituntut pertanggungjawabannya atas tindakan yang dilakukannya. Meskipun demikian, seiring perjalanan waktu perdebatan tersebut akhirnya mendapat titik temu bahwa siapapun yang melakukan perbuatan melawan hukum dan menimbulkan kerugian bagi pihak lain, harus mempertanggungjawabankanperbuatannya, tidak peduli apakah seseorang, badan hukum, maupun pemerintah. ${ }^{19}$

Salah satu prinsip Negara hukum adalah asas legalitas, yang mengandung makna bahwa setiap tindakan hukum pemerintahan harus berdasarkan padaperaturanperundang-

\footnotetext{
18 Tatiek Sri Djatmiati, Hukum Administrasi dan Tindak Pidana Korupsi (Pelayanan Publik dan Tindak Pidana Korupsi). Gadjah Mada University Press, Jogyakarta, 2011. hal. 39.

19 Soerjono Soekanto, Penegakan Hukum, Bina Cipta, Bandung, 1983, hlm. 48-54.
}

undangan yang berlaku atau setiap tindakan hukum pemerintahan harus berdasarkan pada kewenangan yang diberikan oleh peraturan perundang-undangan. Dengan bersandar pada asas legalitas itulah pemerintah melakukan berbagai tindakan hukum. Karena pada setiap tindakan hukum itu mengandung makna penggunaan kewenangan, maka di dalamnya tersirat adanya kewajiban tanggungjawaban, sesuai dengan prinsip "geen bevoegdheid zonder verantwoordelijkheid". Berkaitan dengan hal tersebut, menurut Tatiek Sri Djatmiati $^{20}$ ada dua bentuk tanggungjawab, yaitu (1) tanggungjawab pribadi dan (2) tanggungjawab jabatan.

Tanggungjawab pribadi, berkaitan dengan pendekatan fungsionaris atau pendekatan perilaku. Dari sudut pandang hokum administrasi, tanggungjawab pribadi berkenaan dengan maladministrasi dalam penggunaan wewenang dalam pelayanan public (public service). Penggunaan wewenang yang dimaksud disini meliputi tindakan pemerintahan menurut ketentuan peraturan perundang-undangan dan tindakan dalam menetapkan suatu kebijakan atau diskresi.

Sedangkan tanggungjawab jabatan berkenaan dengan legalitas (keabsahan) tindak pemerintah. Dalam hokum administrasi persoalan legalitas tindak pemerintahan berkaitan dengan pendekatan terhadap kekuasaan pemerintah. Sehingga,

${ }^{20}$ Tatiek Sri Djatmiati, Hukum Administrasi dan Good Governance (Maladministrasi dalam Praktek Kesalahan Pribadi dan Kesalahan Jabatan, Tanggungjawab Pribadi dan Tanggungjawab Jabatan). Universitas Trisakati, Jakarta, 2010. hal. 94. 
dalam pendekatan ini menentukan control atau pengawasan terhadap penggunaan kekuasaan.Dalamhalterdapatpenyimpangan atau pelanggaran terhadap penggunaan kekuasaan oleh pemerintah, maka tanggungjawab Negara dilakukan atas dasar asas legalitas atau asas "rechtmatigheid".

Dalam kamus hukum ada dua istilah yang menunjuk pada pertanggungjawaban yakni liability (the state of being liable) dan responsibility (the state or fact being responsible). Liability merupakan istilah hokum yang luas (a broad legal term), di dalamnya antara lain mengandung makna bahwa, "It has been referred to as of the most comprehensive signicance, including, almost every character of hazard or responsibility, absolute, contingent, or likely. It has been defined to mean: all character of debts and abligations" (liability menunjuk pada makna yang paling komprehensif, meliputi hampir setiap karakter risiko atau tanggung jawab, yang pasti, yang bergantung, atau yang mungkin. Liability didefinisikan untuk menunjuk: semua karakter hak dan kewajiban). Di samping itu, liability juga merupakan; "Condition of being actually or potentially subject to an obligation; condition of being responsible for a possible or actual loss, penalty, evil, expense, or burden; condition which creates a duty to perform an act immediately or in the

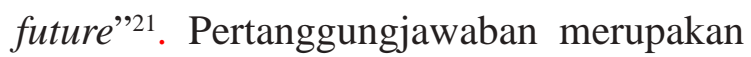
syarat mutlak bagi suatu pemerintahan demokrasi walaupun political responsibility is actually some what ambigious. ${ }^{22}$

\footnotetext{
${ }^{21}$ Hendry Campbell Black, Op.cit., hlm. 823.

22 Suwoto Mulyosudarmo, Peralihan Kekuasaan; Kajian Teoritis dan Yuridis Terhadap Pidato Nawaksara,
}

\section{Kedudukan Presiden Republik Indonesia Dalam Pemerintahan}

Hakikat terdalam dari suatu konstitusi berakar kuat pada eksistensi Negara sebagai organisasi kekuasaan, sehingga keduanya tidakk dapat dipisahkan. ${ }^{23}$. Pada hakekatnya, teori konstitusi sebagai alat untuk membedah permasalahan pertanggungjawaban Presiden terkait erat dengan keberadaan konstitusi sebagai hukum dasar Negara yang mengatur cara rakyat menyelenggarakan kedaulatannya dalam suatu sistem ketatanegaraan. ${ }^{24}$ Oleh sebab itu tidak keliru jika konstitusi ditempatkan sebagai inti dari hukum tata Negara. ${ }^{25}$ Dengan kedudukan yang demikian, keberadaan konstitusi merupakan sumber hukum yang melandasi semua sistem penyelenggaraan kekuasaan pemerintahan rakyat (demokrasi) ${ }^{26}$.

Teori-teori konstitusi tersebut, dalam kaitannya dengan kedudukan Presiden dalam pemerintahan dapat dilihat pada ketentuan UUD 1945 pada Pasal 4 ayat (1) "Presiden Republik Indonesia memegang kekuasaan pemerintahan menurut Undang-Undang Dasar", kandungan makna ketentuan tersebut adalah bahwa Presiden sebagai Kepala Pemerintahan dalam melaksanakan kekuasaan pemerintahannya harus sejalan dengan kehendak UUD 1945. Artikulasi tersebut mengingatkan pada pengamalan Gramedia, Jakarta, 1997, hlm. 1.

${ }^{23}$ Sri Soemantri, Prosedur dan Sistem Perubahan Konstitusi, Alumni, Bandung, 1987, hlm. 2.

${ }^{24}$ K.C. Wheare, Konstitusi-Konstitusi Modern, Terjemahan Moh. Wardani, Pustaka Eureka, Surabaya, 2003, hlm. 1.

${ }^{25}$ Astim Riyanto, Teori Konstitusi, Yapemdo, Bandung, 2003, hlm. 10.

${ }^{26}$ Deddy Ismatullah, Gagasan Pemerintahan Dalam Konstitusi Medinah Ditinjau dari Prinsip-Prinsip Negara Hukum, Disertasi, PPS Unpad, Bandung, 2003, hlm. 13. 
ketentuan UUD 1945 Pasal 1 ayat (2) "Kedaulatan berada di tangan rakyat dan dilaksanakan menurut Undang-Undang Dasar". Jika demikian adanya, berarti adanya kekuasaan Presiden dalam pemerintahan menurut UUD 1945 merupakan perwujudan kedaulatan rakyat dengan adagium "dari rakyat, oleh rakyat, dan untuk rakyat". Oleh sebab itu segala pelaksanaan kekuasaan pemerintahan yang dilakukan Presiden wajib dipertanggungjawabkan dihadapan rakyat. Akan tetapi timbul beberapa pertanyaan, yakni apa bentuk kedaulatan rakyat yang dimaksud UUD 1945 dan bagaimana sistem pertanggungjawaban Presiden dihadapan rakyat?

Secara gramatikal dapat diberikan sebuah jawaban meskipun singkat untuk dijadikan sebuah dasar jika dikemudian ada yang mengembangkannya, bahwa bentuk kedaulatan rakyat sebagaimana tersurat dalam Pasal 1 ayat (2) UUD 1945 sesungguhnya terbentuk dalam substansi pasal-pasal dalam UUD 1945, sedangkan sistem pertanggungjawaban Presiden dihadapan rakyat adalah kembali merujuk pada bentuk kedaulatan rakyat itu sendiri, yakni isi ketentuan UUD 1945, seperti salah satunya adalah jika Presiden melakukan pelanggaran hukum, maka sistem pertanggungjawabannya dilakukan dengan cara seperti yang diatur dalam Pasal 7A dan Pasal 7B UUD 1945 dan ketentuan lainnya.

\section{Sistem Pertanggungjawaban Presiden}

I Gede Pantja Astawa dalam pandangannya memahami sistem sebagai suatu yang memiliki spectrum sangat luas, baik fisik (materil) maupun nonfisik (immaterial). ${ }^{27}$ Luasnya spectrum tentang sistem, terkadang menimbulkan kesulitan untuk memahaminya, terlebih jika dihubungkan dengan suatu kualifikasi tertentu. ${ }^{28}$

Sistem menurut Kusnardi cenderung merujuk kepada metode organis yang memahami sistem sebagai keseluruhan, terdiri dari beberapa bagian yang mempunyai hubungan fungsional, baik antara bagian-bagian maupun hubungan fungsional terhadap keseluruhannya, sehingga hubungan itu membentuk suatu ketergantungan (mutual) antara bagian-bagian yang berakibat gangguan kestabilan dan keseimbangan sistem secara keseluruhan jika salah satu bagian mengalami gangguan. ${ }^{29}$

Sistem merupakan rangkaian unitunit atau elemen-elemen dengan fungsi masing-masing, saling berinteraksi dalam menyelenggarakan fungsinya sebagai satu kesatuan untuk mencapai satu tujuan bersama dan bersifat terus-menerus. Ciri paling dominan untuk menyebut kualifikasi suatu sistem terikat pada fungsi suatu sistem yang terangkai dalam hubungan unit-unit organ dalam suatu sistem besar. Uraian tersebut dapat dipahami bahwa sistem pertanggungjawaban Presiden merupakan suatu unit fungsi sistem tersendiri dalam suatu sistem ketatanegaraan yang terdiri

${ }^{27}$ I Gede Pantja Astawa, Hak Angket dalam Sistem Ketatanegaraan Indonesia Menurut UUD 1945, Disertasi, PPS Unpad, Bandung, 2000, hlm. 4.

${ }^{28}$ Lili Rasjidi dan I.B. Wyasa Putra, Hukum Sebagai Sistem, Mandar Maju, Bandung, 2001, hlm. 52-59.

${ }_{29}$ Moh. Kusnardi dan Harmaily Ibrahim, Pengantar Hukum Tata Negara Indonesia, FH-UI, Jakarta, 1988, hlm. 171. 
dari rangkaian unsur-unsur yang paling berkaitan dengan fungsi masing-masing untuk mencapai satu tujuan bersama yakni pemerintahan yang accountable dalam sistem ketatanegaraan. ${ }^{30}$

Sistem pertanggungjawaban Presiden merupakan salah satu subsistem dari sistem ketatanegaraanyang secarakhusus dirancang dalam suatu UUD untuk mengontrol dan mengendalikan kekuasaan dan wewenang yang diberikan kepada Presiden agar tetap konsisten menegakkan nilai-nilai konstitusional sesuai dengan fungsi-fungsi kekuasaan yang diberikan kepadanya. Hal tersebut senafas dengan filsafat demokrasi ${ }^{31}$ dan faham konstitusionalisme ${ }^{32}$, kemudian dipertegas oleh Lord Acton "power tends to corrupt and absolute power tends to corrupt absoluty" ${ }^{33}$. Oleh karena itu, berbicara tentang pertanggungjawaban kekuasaan, dan secara khusus pertanggungjawaban Presiden merupakan mata rantai yang tidak terpisahkan dari sistem pengawasan kekuasaan dalam filsafat demokrasi dan paham konstitusionalisme. ${ }^{34}$

Merupakan sebuah harapan baru bagi lembaga penegakkan hukum, penyebab adanya hambatan dalam memberantas kejahatan yang dilakukan oleh elit politik yang sebelumnya dibatasi oleh adanya paham kekuasaan presiden tidak tak

\footnotetext{
${ }^{30}$ Firdaus, Pertanggungjawaban Presiden Dalam Negara Hukum Demokrasi, Yrama Widya, Cet.1, Bandung, 2007, hlm. 140-141.

${ }^{31}$ I Gede Pantja Astawa, Op.cit., hlm. 25.

${ }^{32}$ Adnan Buyung Nasution, Aspirasi Pemerintahan Konstitusional di Indonesia; Studi Sosio-Legal atas Konstituante 1956-1959, Grafiti, Jakarta, 2001, hlm. 1.

${ }^{33}$ Sjachran Basah, Perlindungan Hukum Terhadap Sikap Tindak Administrasi Negara, Alumni, Bandung, 1992, hlm. 6.

${ }^{34}$ Firdaus, Op.cit., hlm. 141.
}

terbatas, namun dengan munculnya berbagai ide atau konsep seperti beberapa pakar di atas, sehingga kekuasaan Presiden tersebut tidak lagi tak terbatas, namun sebaliknya kekuasaan tersebut telah dibatasi melalui pandangan filsafat demokrasi dan paham konstitusionalisme, makna dari filsafat demokrasi dan paham konstitusionalisme dalam kaitannya dengan sistem pertanggungjawaban Presiden merupakan sebuah landasan jika sewaktu-waktu Presiden melanggar nilai-nilai konstitusi maupun demokrasi.

Salah satu filsafat demokrasi Indonesia adalah keadilan social bagi seluruh rakyat Indonesia. Dipandu dengan tujuan Negara Indonesia "melindungi segenap bangsa Indonesia dan seluruh tumpah darah Indonesia, dan untuk memajukan kesejahteraan umum, mencerdaskan kehidupan bangsa dan ikut melaksanakan ketertiban dunia yang berdasarkan kemerdekaan, perdamaian abadi dan keadilan sosial..." dapat disimpulkan bahwa Indonesia termasuk Negara hukum kesejahteraan yakni Negara hukum demokrasi (rechtstaat democratie) yang berkeadilan sosial atau Negara hukum materil. Hal itu berarti Presiden dalam menjalankan pemerintahan dimungkinkan untuk mengambil langkah-langakah hukum bersifat interventif atas aktivitas sosial-ekonomi masyarakat dalam rangka kepentingan umum dan kesejahteraan sosial $^{35}$

Argumentasi tersebut bukan tidak diterima, namun perlu dipertegas bahwa

\footnotetext{
${ }^{35}$ Ibid., hlm. 156.
} 
konsep Negara Indonesia adalah Negara hukum bukan Negara hukum kesejahteraan, konsep "kesejahteraan" dalam filosofis bangsa Indonesia adalah apabila proses penegakkan hukum dilaksanakan tanpa adanya perbedaan, karena hakekat Negara hukum adalah memberikan keadilan bagi seluruh rakyat Indonesia, maka secara otomatis berimplikasi pada kesejahteraan bagi seluruh rakyat Indonesia dimana rakyat dapat dengan leluasa mencari kebutuhan hidupnya baik secara materil maupun immaterial. Jika konsep "kesejahteraan" dimasukan dalam konsep Negara hukum, maka eksistensi hukum yang hakekatnya tidakdapatdiukursecarakomprehensifdalam memberikan nilai keadilan bagi seluruh rakyat indonesia, sehingga berimplikasi pada pemahaman bahwa "apabila Negara telah sejahtera, maka hukum tidak berguna lagi”. Perlu diingat bahwa rakyat untuk hukum adalah salah, hukum untuk rakyat adalah tepat.

Sedangkan konsep Negara hukum kesejahteraan yang berimplikasi pada tindakan Presiden dimungkinkan mengambil tindakan interventif atas aktivitas sosialekonomi masyarakat dalam rangka kepentingan umum dan kesejahteraan sosial, juga merupakan konsep yang sampai saat ini telah menghilangkan nilainilai keadilan dalam masyarakat, faktanya adalah dengan berdasar pada konsep Negara hukum kesejahteraan sehingga berimplikasi pada kekuasaan Presiden tidak tak terbatas dimana Presiden dapat melakukan apa saja yang diinginkannya dengan berkedok "untuk kepentingan umum”.
Tanpa disadari konsep tersebut adalah payung atau pelindung bagi para penyelenggara Negara khusunya Presiden selaku penguasa pemerintahan dalam melakukan tindakan-tindakan yang tidak sesuai dengan nilai-nilai keadilan sebagaimanayangterkandung dalamfilosofis Negara demokrasi. Namun konsep tersebut sampai saat ini masih tetap dipertahankan keberadaannya, seperti pada ketentuan Pasal 33 ayat (3) UUD 1945. Ketentuan tersebut berbunyi "bumi dan air dan kekayaan alam yang terkandung di dalamnya dikuasai oleh negara dan dipergunakan untuk sebesarbesar kemakmuran rakyat", pertanyaannya adalah bagaimana bisa Negara menguasai air, pada hakekatnya air itu merupakan anugerah illahi. Kalimat "menguasai" mempunyai makna yang sangat mendalam, salah satunya yakni "setiap masyarakat yang tidak memiliki air, maka untuk memilikinya terlebih dahulu meminta izin kepada Negara (pemerintah)", hal ini bukan merupkan hakekat hukum, justru ini merupakan tindakan abnormal hukum (penyesatan hukum) yang digunakan oleh penguasa. Ketentuan Pasal 33 ayat (3) UUD 1945, mestinya bunyi kalimat baik dan benar adalah "bumi dan air dan kekayaan alam yang terkandung di dalamnya "diatur" oleh negara dan dipergunakan untuk sebesarbesar kemakmuran rakyat". Kalimat "diatur" merupakan kalimat yang mempunyai makna filosofis konstitusional, dimana pemerintah mempunyai kewenangan "regeling" yang secara bersama-sama dibentuk oleh perwakilan rakyat. 
Tanggung Jawab Hukum Presiden dalam Memegang Kekuasaan Pemerintahan

Lembaga Presiden merupakan badan hukum publik, pemangku jabatan hak dan kewajiban dimana kepadanya dapat menuntut dan dituntut di depan peradilan ${ }^{36}$. Menurut Hans Kelsen ${ }^{37}$, kedudukan Negara sebagai badan hukum “...state are personified: the are considered to be "juristic persons in contradiction to "natural person" i.e., humang beings, as subject of duties and rights" (.. ${ }^{38} \mathrm{Negara}$ dipersonifikasikan sebagai pribadi: mereka telah dipertimbangkan sebagai "badan hukum" berbeda dengan "pribadi natura" yakni manusia seluruhnya sebagai subjek hak dan kewajiban). Atas dasar itu, menurut Kelsen, ${ }^{39}$ tanggung jawab hukum dan kewajiban hukum ditujukan kepada badan hukum tetapi "the obligation is incumbent upon individuals who, as competen organs, have to fulfill the duty of the juristic person. It is their behavior that forms the contents of this duty". (kewajiban itu berada di atas pundak individu-individu sebagai organorgan yang berkompeten harus memenuhi kewajiban badan hukum. Perbuatan merekalah yang membentuk isi dari kewajiban ini). ${ }^{40}$

Dihubungkan dengan pendapat Logemann dalam Harun Al Rasid, bahwa jabatan sebagai pribadi (person) dalam hukum tata Negara positif, maka kepada jabatanlah melekat tugas dan wewenang

36 Ibid., hlm. 162 .

${ }^{37}$ Hans Kelsen, General Theory Law and State, New York, Russel \& Russel, 1961, hlm. 68.

${ }^{38}$ Firdaus, Op.cit., hlm. 162.

${ }^{39}$ Hans Kelsen, Op.cit., hlm. 69.

${ }^{40}$ Firdaus, Op.cit. yang digerakkan melalui perantaraanpejabat, sehingga pada konteks pemikiran Kelsen di atas, sikap jabatanlah yang membentuk isi dari kewajiban dan kepadanya dapat dituntut pertanggungjawaban atas tindakan jabatan dalam lembaga Negara (Presiden) walaupun pertanggungjawaban tersebut mewakili jabatannya. ${ }^{41}$

Teori tersebut dikontekstualisasikan dalam UUD 1945 Pasal 7A khususnya kata "Presiden dapat diberhentikan...", maka sangat terang bahwa kedudukan Presiden dalam kalimat tersebut merupakan Pribadi jabatan, karena tidak menyebutkan siapa subjek dari Presiden yang dimaksud, sebab dalam logika organisasi kedudukan Presiden sebagai organ dan lingkup jabatan tidak mungkin diberentikan, melainkan yang dapat diberentikan adalah pemangku jabatan Presiden, sehingga terminologi Presiden pada kalimat di atas ditujukan kepada pribadi pejabat sebagai pemangku jabatan untuk mempertanggungjawabkan perbuatan selama dalam masa jabatan. Pribadi jabatan adalah melekatnya jabatan dalam pribadi seseorang, ketika menduduki suatu jabatan untuk menjalankan organisasi secara sah berdasarkan aturan-aturan yang mengikatnya, sehingga dalam bertindak senantiasa terikat oleh norma hukum yang mengaturnya.

Pemikiran tersebut sejalan dengan doktrin Negara hukum, pemimpin yang sebenarnya bukanlah orang, melainkan hukum sebagai suatu sistem, bagaimana seharusnya Presiden bertindak dalam menjalankan pemerintahan. Gagasan ini

\footnotetext{
${ }^{41}$ Harus Al Rasid, Op.cit., hlm. 5-7.
} 
lazim disebut dengan istilah "the rule of law, and not of man". ${ }^{42}$

Pertanggungjawaban yang dimaksud adalah pertanggungjawaban, baik dalam kapasitas penyelenggara fungsi-fungsi kekuasaan organisasi ataupun pelanggaran hukum yang dilakukan, bahkan pertanggungjawaban sosial karena jabatan yang melekat dalam diri seorang Presiden. Kedudukan Presiden sebagai salah satu lingkupjabatandalamsistem ketatanegaraan, menyebabkan pertanggungjawabanPresiden menjadi diatur secara khusus seperti dalam UUD 1945 Pasal 7B. Oleh karena itu salah satu aspek pertanggungjawaban Presiden adalah pertanggungjawaban jabatan dengan sanksi pemberhentian dari jabatan oleh MPR setelah melalui proses pembuktian atas pertanyaan DPR tentang pelanggaran hukum Presiden di peradilan Mahkamah Konstitusi. $^{43}$

Sependapat dengan argumentasi tersebut bahwa bentuk pertanggungjawaban Presiden dalam UUD 1945 merupakan pertanggungjawaban jabatan, sebab dilihat dari penerapan sanksi yang hanya sebatas pada pemberentian jabatan sebagai Presiden, namun ketentuan tersebut apabila pelanggaran yang dilakukan oleh Presiden terkait dengan kewenangannya sebagai lembaga pemerintahan, misalnya tindak pidana "korupsi", karena jabatannya sehingga ia menerima sebuah hadiah berupa uang dengan maksud

42 Jimly Asshiddiqie, Institusi Kepresidenan Dalam Sistem Hukum Indonesia, Makalah Disampaikan pada Studium Generale di hadapan Dosen dan Mahasiswa Fakultas Hukum Universitas Taruma Negara, Kamis, 28 September 2000, Jakarta, 2000, hlm. 2.

${ }^{43}$ Firdaus, Op.cit. hlm. 163. untuk mempermudah seseorang dalam menggunakan kewenangannya yang pada dasarnya diketahui bahwa kewenangan tersebut tidak dapat diterapkan pada orang tersebut. Terlepas dari pelanggaran jabatannya, sehingga perlu untuk diketahui berbagai tindakan kejahatan yang dapat menghilangkan jabatan Presiden, bukan saja terkait dengan pelanggaran kewenangannya, tetapi adapula pelanggaran yang bukan karena kewenangannya melakukan perbuatan kejahatan, seperti perbuatan pidana lainnya.

\section{Penutup}

Berdasarkan dari rangkaian uraian pembahasan di atas, maka dapat ditarik kesimpulan bahwa tanggung jawab hukum Presiden dalam pemberian izin pemeriksaan bagi pejabat tata usaha Negara dihadapkan pada tanggung jawab hukum administrasi yang didasari oleh paham Negara hukum dan demokrasi yang diatur dalam UUD 1945. Seyogyanya tanggung jawab hukum Presiden tidak saja dihadapkan pada pertanggungjawaban hukum administrasi, namun perlu ditinjau ulang kembali ketentuan Pasal 7A dan 7B UUD 1945, agar prinsip Negara hukum Indonesia dapat mewujudkan hakekat hukum dari apa yang dicita-citakan oleh filosofis demokrasi bangsa Indonesia.

Kembali merujuk pada konsep Negara Republik Indonesia adalah Negara hukum, salah satu hakekat Negara hukum adalah perlindungan hak-hak asasi setiap orang (warga Negara RI), dengan demikian 
maka timbul sebuah konstruksi pemikiran bahwa bagaimana bisa Presiden ketika telah melakukan perbuatan melanggar hukum pidana lainnya seperti menghilangkan "nyawa orang lain" dengan secara sengaja, lalu diberikan sanksi pemberentian jabatan semata, apa norma tersebut telah memberikan nilai keadilan bagi orang yang menjadi korban? Jawabannya tentu setiap orang dalam lintas hubungan sosial kemasyarakatan tidak menginginkan hal seperti itu, seperti pepatah mengatakan "semut saja jika diinjak, pastinya ia menggigit", dan kemudian bagaimanakah dengan asas kesamaan dihadapan hukum (equality before the law)? Perlu dipahami bahwa perbuatan menghilangkan "nyawa orang lain" bukan merupakan perbuatan yang didasarkan dari kewenangannya sebagai lembaga Presiden, tetapi perbuatan itu dilakukan secara batiniah dan rohani, artinya "batinia" jika dalam "keadaan sadar", sedangkan "rohani" dalam "keadaan tidak sadar/atau lalai". Untuk itu, seharunya ketentuan Pasal 7A selain dari pelanggaran hukum yang dilakukan atas kewenanggannya sebagai Presiden (kepala pemerintahan), maka ketentuan perbuatan melanggar hukum lainnya wajib dipertanggungjawabkan secara hukum dan dihadapan hukum, (melalui lembaga peradilan umum). Karena hakekatnya seorang Presiden dalam kepribadiannya merupakan bagian dari masyarakat umum.

\section{DAFTAR BACAAN}

Adnan Buyung Nasution, 2001. Aspirasi Pemerintahan Konstitusional di
Indonesia; Studi Sosio-Legal atas Konstituante 1956-1959, Grafiti, Jakarta.

A.D. Belifante, dalam Diana Halim Koentjoro, 2004. Hukum Administrasi Negara, Ghalia Indonesia, Cetakan Pertama, Bogor.

Astim Riyanto, 2003. Teori Konstitusi, Yapemdo, Bandung.

Deddy Ismatullah, 2003. Gagasan Pemerintahan Dalam Konstitusi Medinah Ditinjau dari PrinsipPrinsip Negara Hukum, Disertasi, PPS Unpad, Bandung.

Dennis F. Thompson, 2002. Political Ethics and Public Office, President and Fellows of Harvard College, 1993. Diterjemahkan oleh Yayasan Obor Indonesia dengan judul, Etika Politik Pejabat Negara, Jakarta.

Firdaus, 2007. Pertanggungjawaban Presiden Dalam Negara Hukum Demokrasi, Yrama Widya, Cet.1, Bandung.

Hendry Campbell Black, 1979.Black's Law Dictionary, Fifth Edition, (USA: ST. Paul Minn, West Publishing Co.

Harun Al Rasid, 1999. Pengisian Jabatan Presiden, Grafiti, Jakarta.

Hans Kelsen, 1961. General Theory Law and State, New York, Russel \& Russel.

I Gede Pantja Astawa, 2000. Hak Angket dalam Sistem Ketatanegaraan Indonesia Menurut UUD 1945, Disertasi, PPS Unpad, Bandung.

Jimly Asshiddiqie, 2000. Institusi Kepresidenan Dalam Sistem Hukum Indonesia, Makalah Disampaikan pada Studium Generale di hadapan Dosen dan Mahasiswa Fakultas 
Hukum Universitas Taruma Negara, Kamis, 28 September 2000, Jakarta. 2010. Perkembangan \& Konsolidasi Lembaga Negara Pasca Reformasi, Sinar Grafika, Edisi Kedua, Cetakan pertama, Jakarta.

K.C. Wheare, 2003. Konstitusi-Konstitusi Modern, Terjemahan Moh. Wardani, Pustaka Eureka, Surabaya.

Lili Rasjidi dan I.B. Wyasa Putra, 2001. Hukum Sebagai Sistem, Mandar Maju, Bandung.

Moh. Kusnardi dan Harmaily Ibrahim, 1988. Pengantar Hukum Tata Negara Indonesia, FH-UI, Jakarta.

Mochtar Kusumaatmadja et. al., 2000. Pengantar Ilmu Hukum: Suatu Pengenalan Pertama Ruang Lingkup Berlakunya Ilmu Hukum, Alumni, Buku I, Bandung.

Philipus M. Hadjon, 2010. Hukum Administrasi dan Good Governance, Universitas Trisakti, Jakarta.

Paulus E. Lotulung, 1993. Beberapa Sistem Tentang Kontrol Segi Hukum Terhadap Pemerintah, Citra Aditya Bakti, Bandung.

Ridwan HR, 2011. Hukum Administrasi Negara, Edisi Revisi, Rajawali Pers, Jakarta.
Sjachran Basah, 1992. Perlindungan Hukum Terhadap Sikap Tindak Administrasi Negara, Alumni, Bandung.

SJ. Fockema Andreae, 1951. Rechtsgeleerd Handwoordenboek, Tweede Druk, J.B. Wolter, Uitgevers-maatshappij N.V., Groningen.

Soerjono Soekanto, 1983. Penegakan Hukum, Bina Cipta, Bandung.

Soejono Soemargono, 1995. Pengantar Filsafat, Tiara Wacana, Cetakan Keenam, Yogyakarta.

Suwoto Mulyosudarmo, 1997. Peralihan Kekuasaan; Kajian Teoritis dan Yuridis Terhadap Pidato Nawaksara, Gramedia, Jakarta.

Sri Soemantri, 1987. Prosedur dan Sistem Perubahan Konstitusi, Alumni, Bandung.

Tatiek Sri Djatmiati, 2010. Hukum Administrasi dan Good Governance (Maladministrasi dalam Praktek Kesalahan Pribadi dan Kesalahan Jabatan, Tanggungjawab Pribadi dan Tanggungjawab Jabatan). Universitas Trisakati, Jakarta.

Tatiek Sri Djatmiati, 2011. Hukum Administrasi dan Tindak Pidana Korupsi (Pelayanan Publik dan Tindak Pidana Korupsi). Gadjah Mada University Press, Jogyakarta. 
232 Yuridika: Volume 27 No 3, September-Desember 2012 